\title{
Agronomic Management for Enhancing Plant Tolerance to Abiotic Stresses-Drought, Salinity, Hypoxia, and Lodging
}

\author{
Luigi Mariani ${ }^{1,2}$ and Antonio Ferrante ${ }^{2, *}$ \\ 1 Lombardy Museum of Agricultural History, via Celoria 2, 20133 Milan, Italy; luigi.mariani@unimi.it \\ 2 Department of Agricultural and Environmental Sciences, Università degli Studi di Milano, via Celoria 2, \\ 20133 Milan, Italy \\ * Correspondence: antonio.ferrante@unimi.it
}

Academic Editors: Alessandra Francini and Luca Sebastiani

Received: 26 September 2017; Accepted: 21 November 2017; Published: 1 December 2017

\begin{abstract}
Abiotic stresses are currently responsible for significant losses in quantity and reduction in quality of global crop productions. In consequence, resilience against such stresses is one of the key aims of farmers and is attained by adopting both suitable genotypes and management practices. This latter aspect was reviewed from an agronomic point of view, taking into account stresses due to drought, water excess, salinity, and lodging. For example, drought tolerance may be enhanced by using lower plant density, anticipating the sowing or transplant as much as possible, using grafting with tolerant rootstocks, and optimizing the control of weeds. Water excess or hypoxic conditions during winter and spring can be treated with nitrate fertilizers, which increase survival rate. Salinity stress of sensitive crops may be alleviated by maintaining water content close to the field capacity by frequent and low-volume irrigation. Lodging can be prevented by installing shelterbelts against dominant winds, adopting equilibrated nitrogen fertilization, choosing a suitable plant density, and optimizing the management of pests and biotic diseases harmful to the stability and mechanic resistance of stems and roots.
\end{abstract}

Keywords: drought; lodging; hypoxia; salinity

\section{Introduction}

Crop yield and quality are the result of the interaction between a genotype's potential expression and the environment, which is modified by agronomic management in order to meet the objectives of the farmer. Different genotypes have varying yield capabilities depending on their adaptation abilities [1]. Agricultural systems are continuously evolving due to innovation in agronomic tools and the identification of high-performance cultivars coming from traditional or biotechnological genetic improvements [2]. Abiotic stresses such as low water availability, high salinity, high or low temperatures, hypoxia/anoxia, and nutrient deficiency are among the major causes of crop failure. Plants are able to perceive environmental stimuli and adapt to different environments; however, the degree of tolerance and adaptability to abiotic stresses varies among species and varieties. Crops exposed to abiotic stresses respond by activating defense mechanisms. Therefore, crops in an early stage of stress do not show visible symptoms but their physiology can undergo significant changes [3]. The energy used to counteract or cope with abiotic stresses is called "fitness cost" and does not contribute to crop production. Crops have to balance the resource allocation between productivity and defense actions [4].

In this review, agronomic strategies aimed at optimizing the resilience of crops exposed to abiotic stresses are covered. The work has been divided into two parts and the second part will 
be related to stress due to nutrients, high and low temperatures, and light excess or deficiency. Every agronomic strategy presented and discussed hereafter is sustainable not only socially and environmentally but also economically, because agriculture is an economic activity that cannot be done without adequate remuneration.

\section{Role and Impact of Abiotic Limitations to Crop Yield}

The general scheme proposed in Figure 1 describes the plant response to an abiotic stress with given features (duration, severity, etc.). The stress acts on a crop with given phenotypic characters to result in the final effects on growth, development, and mortality rate [5]. The basic scheme of Figure 1 is the result of a complex causal chain, which involves plant hormones and acts at the molecular and physiological level. The knowledge of this causal chain is substantially increasing thanks to transcriptomics, metabolomics, proteomics, and other integrated research approaches [3]. The conceptual scheme illustrated in Figure 2, widely adopted in crop yield simulation [6,7], shows crop production as the final result of a dry matter cascade triggered by solar radiation intercepted by plant canopies, which provides energy for the photosynthetic process.

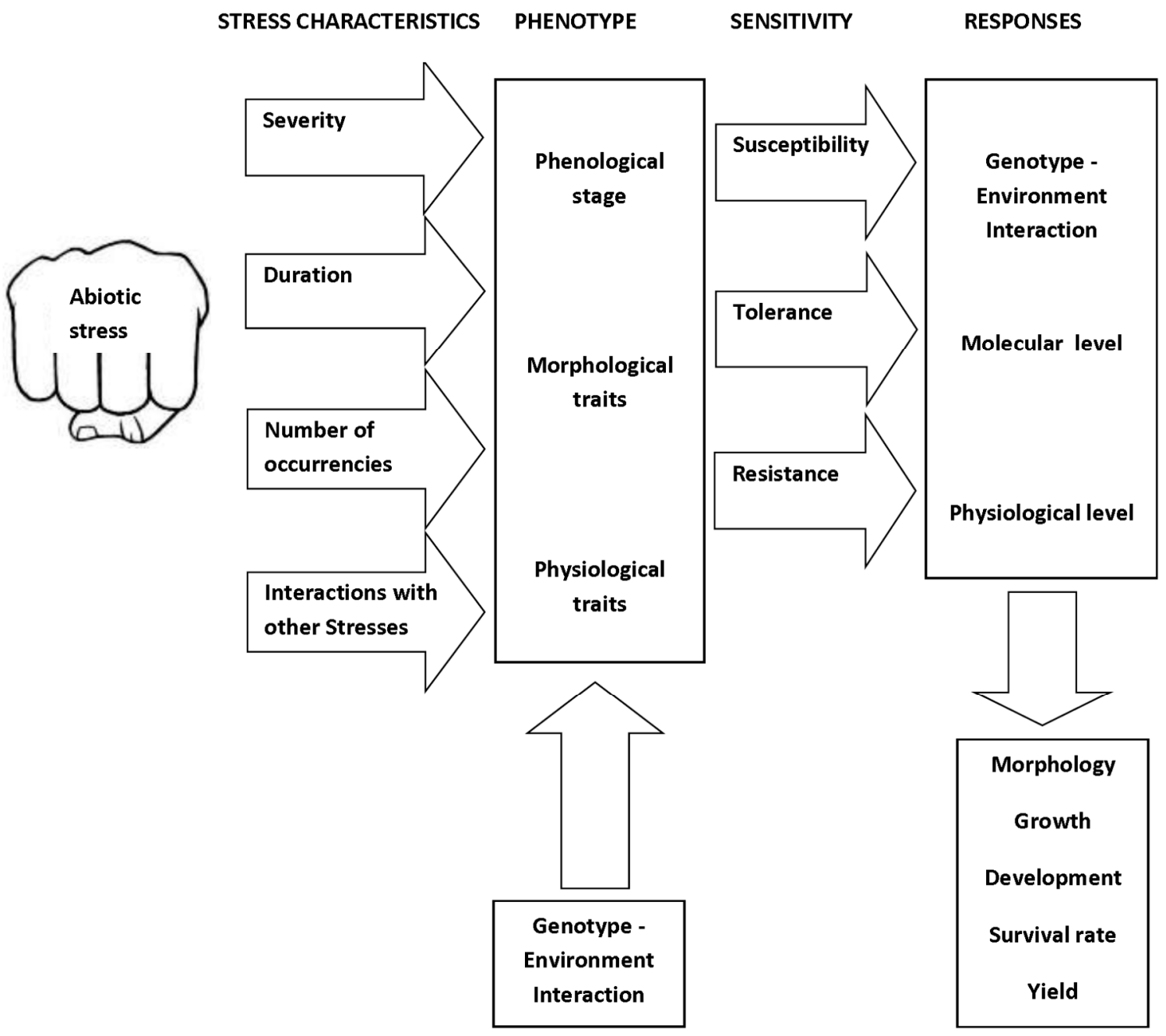

Figure 1. Scheme of factors that determine crop response to abiotic stresses. 


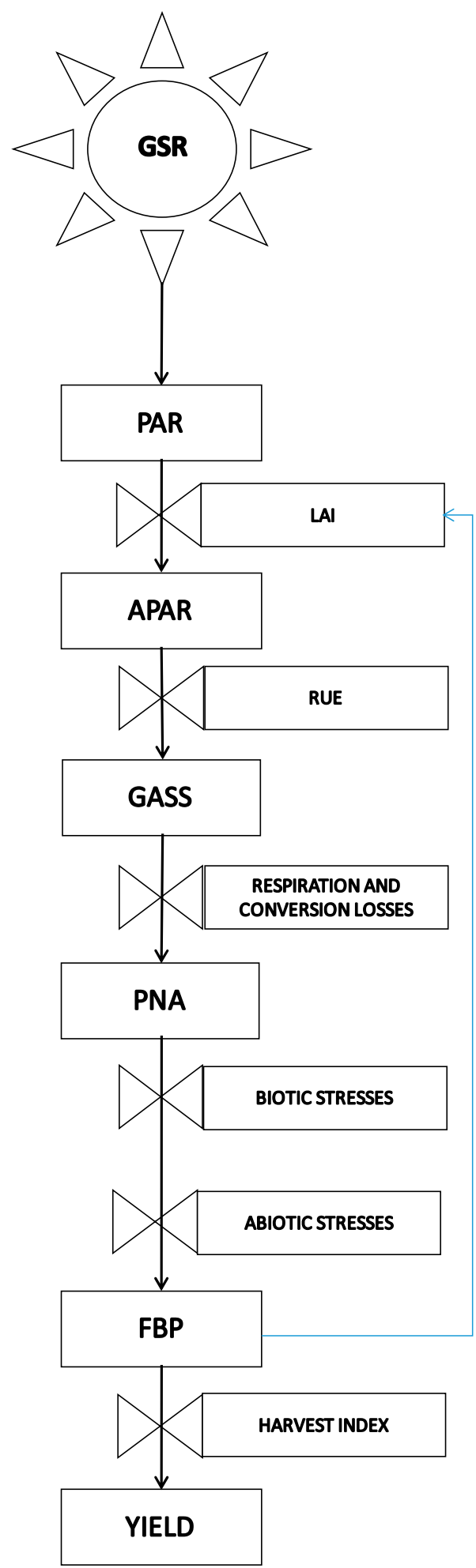

Figure 2. Conceptual scheme of the cascade of energy and organic matter that links global solar radiation and final yield. The role of abiotic stress as a rate variable that rules the conversion from potential net assimilation (PNA) to the final biomass production (FBP) is highlighted, with global solar radiation (GSR), photosynthetically active radiation (PAR), absorbed PAR (APAR), and gross photosynthetic assimilation (GASS) each contributing to the outcome. Rectangular boxes are state variables, and valves are rate variables. 
Photosynthesis gives rise to a potential production of dry matter, gradually curtailed by different losses up to final production. Important losses occur by conversion from global solar radiation (GSR) to photosynthetically active radiation (PAR), efficiency of photosynthesis, translocation from photosynthetic to storage organs, maintenance and production respiration, and limitations by biotic (pests, fungi, bacteria, weeds, and so on) and abiotic stresses (temperature, soil water excess or shortage, nutrients, wind, etc.).

An example of a grain maize (class 700 FAO) field crop with Radiation Use Efficiency (RUE) of $4 \mathrm{~g}$ of glucose per MJ of Absorbed Photosynthetically Active Rradiation (APAR) and a harvest index (HI) of 0.6 cultivated on a flat plain at $45^{\circ}$ North is useful to give an idea of the strength of the effect of different limitations on crop production. This field received $4337.0 \mathrm{MJ} \cdot \mathrm{m}^{-2}$ of GSR in the period 1 April-30 September (data for Piacenza San Damiano, Italy-mean of the period 1993-2013); $50 \%$ of the GSR was useful for photosynthesis (PAR $=2168.5 \mathrm{MJ}$ ) and $80 \%$ of the PAR was intercepted by the canopy (APAR $=1734.8 \mathrm{MJ} \cdot \mathrm{m}^{-2}$ ). By consequence, the Gross Assimilation (GASS) was $1734.8 \mathrm{MJ} \cdot \mathrm{m}^{-2} \cdot 4 \mathrm{~g} \cdot \mathrm{MJ}^{-1} \cdot 10,000 \mathrm{~m}^{2} \cdot 1 / 1,000,000 \mathrm{t} \cdot \mathrm{g}^{-1}=69.4 \mathrm{t} \cdot \mathrm{ha}^{-1}$ of glucose.

If we consider a loss of $35 \%$ related to maintenance and production respiration and translocation of photosynthetic products from the green organs to the storage tissues [8], there was a total net production without limitations (Potential Net Assimilation, PNA) of $69.4 \times(1-0.35)=45.1 \mathrm{t} \cdot \mathrm{ha}^{-1}$, which, multiplied by HI, gives a potential net grain production of $27.1 \mathrm{t} \cdot \mathrm{ha}^{-1}$. This latter value was $48 \%$ higher than ordinary production and $33 \%$ higher than the maximum production attainable in ideal field conditions (Table 1). These gaps give an idea of the weight of biotic and abiotic stress factors in ordinary field conditions on the Po plain (Italy). In our experience, the weight of biotic factors (mainly effects of the European corn borer Ostrinia nubilaris and some fungal diseases) is about 15\%, as can be inferred by comparing Italian production trends with those of the USA, where GMO BT maize largely eliminates the effects of biotic stresses from European corn borer and related fungal diseases. As a consequence, the effect of abiotic stresses on maize yield is about $33 \%(15-48 \%)$ in ordinary field conditions and drops to 18\% (15-33\%) in ideal field conditions (Table 1). Global values of abiotic limitations were simulated by Mariani [8] with a physiological-process-based crop simulation model driven by 1961-1990 monthly climate data from a global FAO dataset and applied to four crops (Wheat, Maize, Rice, and Soybeans (WMRS)) that account for $64 \%$ of global caloric consumption by humans. The model simulated only temperature and water limitations.

Table 1. The gap between net potential assimilation and final yield for maize cultivated in the Po valley in Italy [8].

\begin{tabular}{|c|c|c|c|}
\hline $\begin{array}{l}\text { Maize (Class } 700 \text { FAO) Yield in Field } \\
\text { Conditions on the Po Plain (Italy) }\end{array}$ & $\begin{array}{c}\text { Total Biomass } \\
\text { Production }\left(t \cdot h a^{-1}\right)\end{array}$ & $\begin{array}{c}\text { Harvest } \\
\text { Index }(\%)\end{array}$ & $\begin{array}{l}\text { Grain Yield } \\
\left(\mathrm{t} \cdot \mathrm{ha}^{-1}\right)\end{array}$ \\
\hline Potential net assimilation (PNA) & 45.1 & 0.6 & 27.1 \\
\hline Ordinary farmer objective in field conditions & 21.7 & 0.6 & 13 \\
\hline Highest yield reachable in field conditions & 30 & 0.6 & 18 \\
\hline
\end{tabular}

As stated by Mariani [8], (i) the simulation was carried out on a global map with a pixel of $0.50 \times 0.50$ degrees in geographic coordinates (about $60 \times 60 \mathrm{~km}$ at the equator), (ii) thermal and water limitations at the different latitudes were estimated only for the cells where the selected crops were present, (iii) water limitation for rice was estimated for rainfed crops and water, (vi) thermal limitations were obtained with suitable response curve models, and (v) the final weight of limitations on crop production was obtained by adopting a multiplicative approach.

The results in Figure 3 show the strength of global abiotic limitation and substantially agree with the results given by Buchanan et al. [5]. Moreover, the latitudinal distribution of abiotic limitations is shown in Figure 4. 


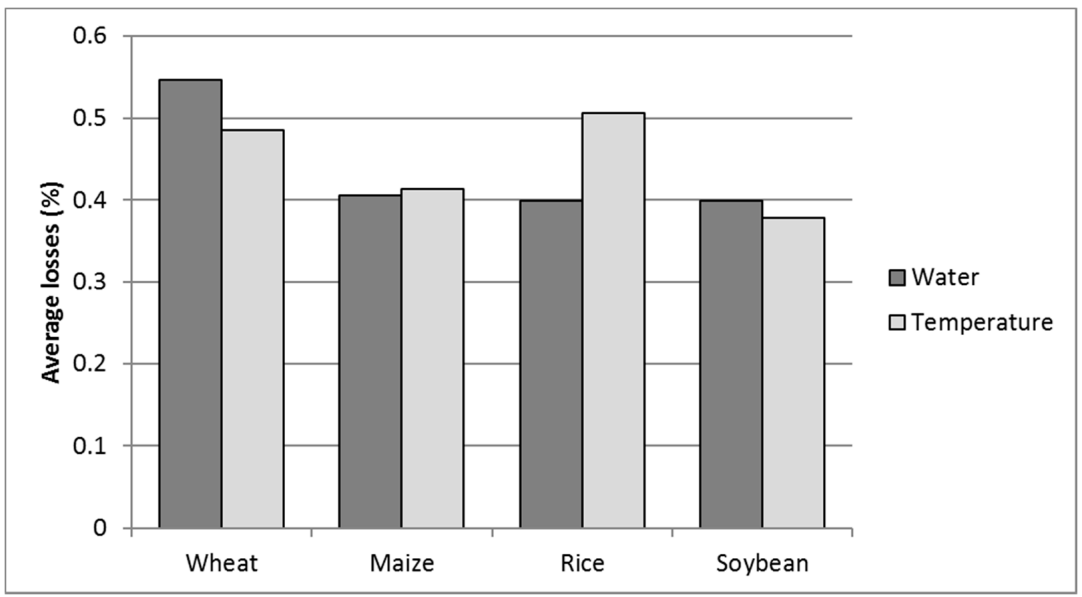

Figure 3. Mean global water and temperature stress losses for the four selected crops, wheat, maize, rice, and soybeans (WMRS) (\% on potential net assimilation. PNA). Values above 1 of cumulative water and temperature stresses are the result of non-additive effects of multiple stresses [8].

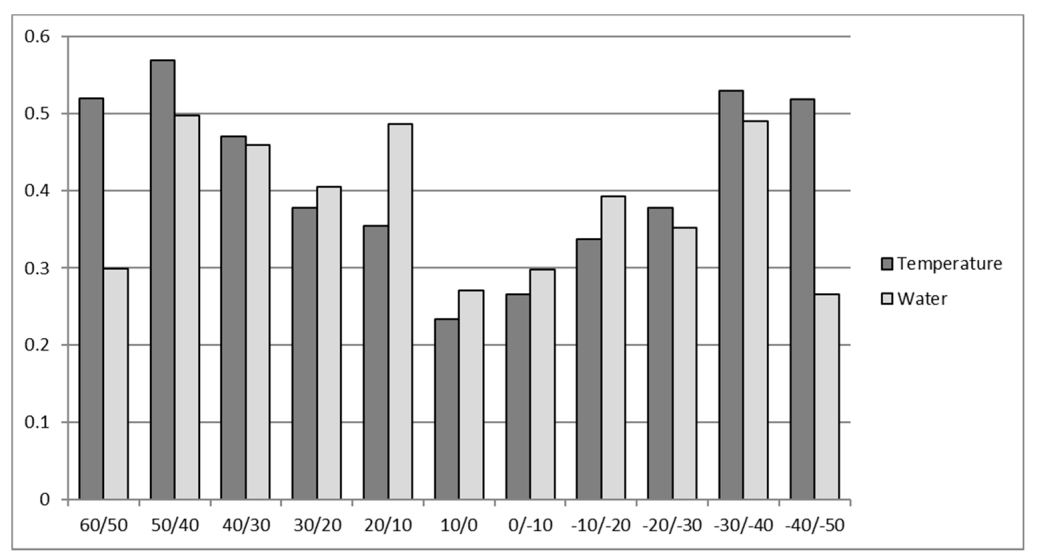

Figure 4. Mean latitudinal water and temperature stress for the four selected crops (WMRS). Values above 1 of cumulative water and temperature stresses are admissible due to the non-additive effects of multiple stresses [8].

Abiotic stresses interact not only among themselves but also with biotic stresses. For example, a crop that has undergone abiotic stress often shows greater susceptibility to attacks from insects, fungi, or mites, and a crop prone to these attacks shows greater sensitivity to water stress because stomata regulation is altered. Oerke [9] provided a global evaluation of the weight of biotic stresses due to weeds, pests, and pathogens for maize and wheat (two staple crops responsible for about $45 \%$ of global caloric intake by humans) and cotton (a commodity fundamental for the production of consumer goods). Data from three reference periods (1964-1965, 1988-1990, and 2001-2003) showed weights of $23.9 \%, 34.0 \%$, and $28.2 \%$ for wheat; $34.8 \%, 38.3 \%$, and $31.2 \%$ for maize; and $24.6 \%, 37.7 \%$, and $28.8 \%$ for cotton, respectively. The global weight of biotic stresses on yield losses was estimated to be $70 \%$ by Boyer [10] and 13-94\% by Farooq et al. [11]. Other data that illustrates both global yield losses and the weight of abiotic stresses have been reported by Cramer [4]. All the above mentioned estimates state the relevant gap between potential and real crop production induced by both biotic and abiotic stresses. 


\section{Soil Texture, Structure, and Field Hydraulic Arrangements}

Plant resilience against abiotic stresses is at a maximum if soil conditions are suitable for plant growth and development. Soil is a disperse three-phase system, and a medium-textured soil at a condition considered optimal for plant growth is schematically composed (by volume) of 50\% solid matter (textural particles and organic matter) and $50 \%$ pore space. The latter is equally divided between $25 \%$ liquid (circulating solution) and $25 \%$ gas (soil atmosphere) and an increase in liquid is associated with a decrease in gas and vice versa [12].

A suitable presence of oxygen is crucial for growth and deployment of roots that give an easy access to water and nutrients, and a suitable anchorage [13]. So, a relevant deviation from the abovementioned solid-liquid-gas (slg) volume ratio caused by an excess or shortage of water or by pore volume decrease by compaction strongly affects root growth and deployment, thus affecting crop production [14]. Obviously, the response to unsuitable slg volume ratios is strongly influenced by species and varieties, as testified by the case of ruderal weeds like Plantago spp. and Polygonum aviculare that are able to colonize compacted soils.

In medium- and fine-textured soils, a volume ratio suitable for most crops is generally attained if colloids (clay and organic matter) aggregate solid elements of texture in structural particles with a diameter of $0.3-3 \mathrm{~mm}$, giving rise to a so-called granular structure, with pores characterized by a 50-50 ratio between macropores (large soil pores generally greater than $0.08 \mathrm{~mm}$ in diameter, which, after a saturating rainfall or irrigation, are rapidly drained and re-occupied by air) and micropores (small soil pores with diameters less than $0.08 \mathrm{~mm}$ that are mainly found within structural aggregates) [15].

As stated by Valentine et al. [16], who worked on 34 farms located in eastern Scotland that represented a wide range of soil types, textures, crop rotation, and farm management practices, root elongation was directly correlated with the volume of large pores $(60-300 \mu \mathrm{m})$ and inversely correlated with penetrometer resistance. More specifically, root elongation was enhanced by low-resistance macropores, which overcome mechanical impedance due to the strength of the bulk soil and are limited by hypoxia (or some combination of hypoxia and soil strength) if the rate of oxygen diffusion to the root surface is too low.

Degradation of the granular structure towards structural states less favorable to crops (columnar, blocky, prismatic, massive, etc.) can result from various natural and man-made factors such as the effect of heavy rain on naked soil or the effect of preparatory or tillage carried out under unfavorable conditions of soil water content. Particularly damaging are field activities carried out with excessive soil water content. This explains, at least in part, the importance of hydraulic agricultural systems that aim to avoid excessive water due to rainy or saturated irrigation or high ground.

A fundamental presupposition to reach and maintain the granular structure is to avoid soil water excess; this can be attained by means of suitable soil field hydraulic arrangements. The basic rules for the field management of precipitation are that (1) soil water reservoir must be refilled until field capacity, (2) water excess must be quickly removed from field because it is harmful to most crops, and (3) the speed of this removal must be compatible with the need to avoid harmful erosion phenomena. Field hydraulic arrangements (ditches and drainage systems) should follow these general rules. According to Bonciarelli [17], primary field ditches should be sized with reference to the heavy and frequent rainfall that was quantified for Italy at $50 / 70 \mathrm{~mm}$ in $24 \mathrm{~h}$, which means a reference volume for primary field ditch volumes of 250 to $350 \mathrm{~m}^{3} \cdot \mathrm{ha}^{-1}$. This basic volume should be significantly reduced for very permeable soils. A quantitative analysis carried out by Mariani et al. [18] on rainfall data of 98 stations from throughout Italy, which mainly belongs to the Köppen-Geiger climate types Csa and Cfa, taking into account the 8th absolute $24 \mathrm{~h}$ rainfall maximum for the 1993-2012 period, highlighted that most of the territory needed a ditch volume of 250 to $350 \mathrm{~m}^{3} \cdot \mathrm{ha}^{-1}$, as indicated by Bonciarelli [17], with some significant exceptions. 
Table 2 lists factors that determine the conservation and improvement of granular structures. Minimum tillage and no tillage aim to promote the self-healing capacity of soils [19-21] and are particularly effective in soils with a sufficient content of good-quality clays.

A significant improvement of structure is also observed with soil organic or inorganic mulching [22] and with soil tillage carried out at a moisture content that maximizes the number of small aggregates [23]. Granular structure can be maintained or enhanced by amendments with organic matter like manure, slurry, compost, crop residues [24,25], or macromolecule polymers acting as soil conditioners [26,27]; or by mixing two or more soil layers in order to reach a more equilibrated texture [28]. Amendments improve soil physical properties, including increasing the content of water-stable aggregates, improving soil porosity and soil penetrability, improving water retention, decreasing soil bulk density and evaporation, and decreasing runoff amount and velocity.

Significant effects on soil structure are played by different tillage systems (moldboard ploughing, minimum tillage, or no tillage systems) with significant effects on macro- and microporosity. For example, Pagliai et al. [19] showed that minimum tillage significantly increased macroporosity, giving rise to a higher hydraulic conductivity and a less pronounced tendency to form a surface crust. Similar effects were highlighted for tropical soils under a no tillage system for 12 years [21].

Soil degradation factors are also listed in Table 2. Soil degradation due to rain [29] first involves the splash erosion that occurs when raindrops hit bare soil and is followed by runoff with sheet erosion (soil removal in thin layers by shallow surface flow), rill erosion (shallow drainage lines less than $30 \mathrm{~cm}$ deep), gully erosion (channels deeper than $30 \mathrm{~cm}$ that cannot be removed by normal cultivation), and tunnel erosion, which occurs when surface water moves into and through dispersive subsoils $[30,31]$.

Heavy traffic of agricultural machinery is responsible for surface and subsurface soil compaction $[28,32]$, which can be prevented by the adoption of machinery tracked or wheeled with low-pressure tires.

A relevant soil degradation factor is given by freezing-thawing cycles [33], such as the triggering factor for the peculiar type of gully erosion (named "calanchi" in Italian) that is typical of the Apennine clayey hills. The "calanchi" are more frequent in slopes exposed to the south, which are prone to freezing-thawing cycles.

Table 2. List of factors that determine conservation and improvement or degradation of granular soil structure.

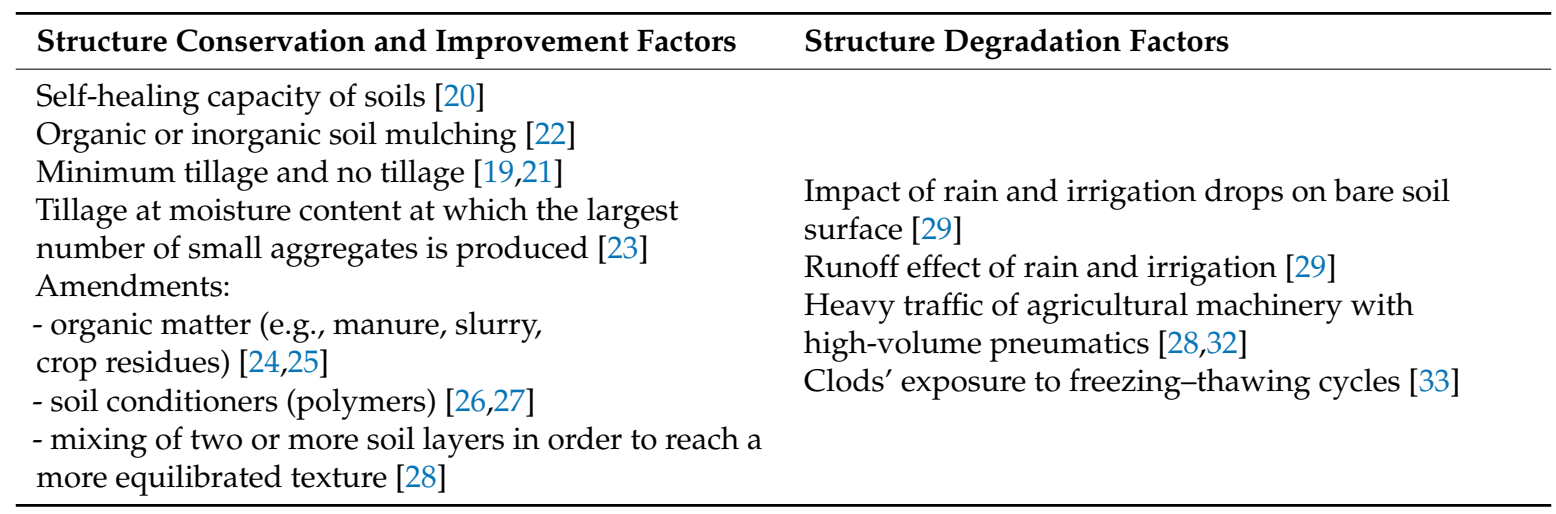

\section{The Impacts of Individual Stress Factors on Crops}

\subsection{Hypoxia/Anoxia Stress}

Crops exposed to limited oxygen conditions must modify their physiology, biochemistry, and transcript profiles to adapt to stressful environments. Crop adaptability can allow survival if exposed to extreme environments or adverse seasons. Several physiological pathways are 
modified or activated, and many others are repressed [34], to allow plant survival. Specific stress activates a target gene or cluster of genes that may work as signals for cascade activation events and secondary responses [35]. Hypoxia or anoxia is quite a common event that can occur during plant life. During rainy seasons, plants can undergo long periods of flooding and suffer from waterlogging. However, waterlogging can also occur after excessive irrigation in soils with poor drainage. Crops under flooding conditions suffer from low oxygen availability at the root level, which causes a reduction of oxygen in tissues and leads to hypoxia/anoxia responses. In agriculture, oxygen limitation can cause a reduction in crop yield [36]. In fact, yields can dramatically decline after a long period of waterlogging: damages depend on adaptability to hypoxic conditions, soil properties, and drainage. In general, surviving oxygen deprivation depends on which plant tissue type is involved, the developmental stage, and the genotype, as well as the severity and duration of the stress light levels and temperature [37].

The agronomic strategies that can be applied to avoid flooding during the winter provide adequate drainage and soil arrangements, especially where there are structural problems [38]. Another important strategy is nitrate supply. Nitrate fertilization is quite uncommon in winter as plants have low metabolic activity and the frequent rain can increase the nitrate leaching. However, it has been proven that nitrate supply increased plant survival during the winter. Subsequently, several experiments demonstrated that increasing nutrient supply in waterlogged wheat increased plant growth and performance [39]. Among the different nutrients, the most important was nitrogen and, in particular, nitrate. In experiments on tomatoes, plants exposed to oxygen deprivation had delayed anoxia symptoms if nitrate was supplied [40]. The main role is not played by nitrate but the nitrate reductase enzyme. This enzyme in hypoxia conditions has been demonstrated to be involved in NO formation, which plays an important role in the hemoglobin oxygenation/reduction cycle [41].

\subsection{Drought Stress and Dry Farming}

Drought can drastically reduce crop productivity, especially if it occurs in the most critical stage of plant development. The crop tolerance to water stress depends on the ability of the plant to undergo physiological, biochemical, and morphological changes to enhance water use efficiency (WUE). Crop physiology is regulated by soil water availability and environmental conditions. With optimal soil water availability, plant transpiration is regulated by environmental variables around the leaves. The reduction of water in soil induces in the plant a regulation of the transpiration rate by reduction of stomatal conductance to equilibrate the amount of water uptake and maintain the crop water balance. It means that crops absorb and transpire the same amount of water; in this situation, soil water availability defines the crop yield. The prolonged decline of water availability induces the plant to produce compounds that enhance crop tolerance. Water movement occurs along gradients of water potentials so during drought conditions, crop plants accumulate osmolytes that are used for cell osmoregulation or osmotic adjustment that maintain water uptake [42]. Plants adapted to low water availability also show (i) morphological changes such as reduced leaf area and increased root biomass for exploring a wide volume of soil to find water, and (ii) phenological changes due to the need to reach maturity or ripening as the primary goal. The reduction of water availability induces several physiological and metabolic changes that lead plants to invest their energy to modify their morphology or produce osmolytes, but that reduce yield.

Only a quarter of land receives enough rain to meet crop water requirements. This explains the birth [43] of dry farming, an ensemble of cropping practices that can be adopted in areas without irrigation and where the annual average precipitation is between about 250 to $500 \mathrm{~mm}$, or where rainy events are highly discontinuous and concentrated in limited periods of the year, as for example in Mediterranean environments (Csa type of Köppen-Geiger climate classification), where less than $30 \%$ of yearly precipitation falls during the summer. In the Mediterranean, water availability during the summer is often the main limiting factor for agriculture. The water shortage reduces yields 
and production can be only achieved by using efficient agronomic water management strategies, while climate variability and change have resulted in more sustainable management of water resources.

Dry farming aims in particular at the conservation of water resources by enhancing the storage of useful water in the soil reservoir and limiting water consumption. These objectives can be achieved by increasing the storage of water useful for crops in the soil reservoir, increasing the depth of the soil layer explored by roots, reducing water loss from the soil reservoir, and improving the crop Water Use Efficiency-WUE (water consumption per unit of dry matter produced).

Increased water storage for crops in the soil reservoir can be obtained in the following ways:

- $\quad$ adopting hydraulic arrangements that slow down the speed of surface water runoff and allow water penetration into soil, refilling the underground water reservoir. The infiltration of surface water can also be enhanced by appropriate tillage (e.g., by surface tillage that increases the roughness of the soil). Different tillage methods have a different effect on soil porosity and water infiltration. Ploughing to the depth of $20 \mathrm{~cm}$ is the tillage system that gives the highest porosity and water storage capacity, while the lowest was obtained in no-tillage systems [44];

- $\quad$ enhancing the drainage of infiltrated water in order to reach the entire profile explored by roots (e.g., by deep tillage carried out with rippers);

- $\quad$ favoring seasonal flooding of soils by water courses;

- catching runoff water and directing it towards compliant areas suitable for agriculture.

The depth of the layer explored by the roots can be increased in the following ways:

- breaking waterproof or compacted layers by means of ripping or ploughing;

- $\quad$ intervening with drainage or filled ditches to contain the winter rise of the water table, which imposes on crops a superficial root system, enhancing their sensitivity to summer drought.

The soil reservoir can be enhanced by:

- adopting management practices useful for promoting a granular structure with a good equilibrium between macro- and microporosity;

- $\quad$ increasing soil organic matter with organic fertilizers or green manure (the positive effect of organic matter on the soil reservoir is more significant in sandy soils or clay soils with low-quality clays-kaolinite). Organic matter increases the water storage ability of soils. Therefore, higher organic matter concentration means higher water availability for a crop [45];

- adjusting soil texture by mixing surface horizons with excess of sand with lower layers richer in clay (the presupposition for this activity is a suitable analysis of the soil profile and horizon distribution);

- $\quad$ adopting fallow techniques (field plowed and harrowed but left unseeded for one year) aimed at accumulating water in the soil during the "rest" period. For example, the biennial rotation fallow-wheat can be a solution for crop areas where yearly rainfall is insufficient for continuous cultivation. In this context, while the naked fallow should be avoided due to erosion problems and negative impacts on humus content, the most rational form of fallow is that of early autumn plowing (before the rainy season) and superficial work (harrowing) during the following spring and summer, whenever the soil appears encrusted or covered by weeds that waste a relevant quantity of water.

The loss of water from the soil reservoir can be limited by:

- minimizing tillage works (minimum tillage, sod seeding) in order to limit water evaporation from clods exposed to air. Superficial tillage usually limits water losses through evaporation since the capillarity is interrupted and water does not reach the soil surface. Water evaporation can be $70 \%$ higher in untilled soils compared with conventional ones [45]. 
- breaking the soil surface layer or soil crust by means of light soil work (harrows or weeders) in order to eliminate soil cracks that increase the exchange surface with the atmosphere and to interrupt the continuity between soil and atmosphere, reducing water flow towards this latter.

- $\quad$ implementing rational control of weeds, which are strong competitors for water. This is very important during the early stages of the crop cycle and the most critical phases in terms of the water deficit;

- reducing evaporation and transpiration loss through shading, windbreaks, mulching, and anti-hail nets. For example, on tendon-grapevines in Apulia (Italy), plastic films and/or anti-hail nets are used as cover in order to anticipate or delay the harvest and to reduce respiratory losses thanks to the shading effect and the limitation of the transpirational flow. Mulching with plastic or biodegradable films is commonly used in vegetable production to reduce water losses by evaporation and irrigation requirements [46,47]. A reduction of $45 \%$ of water need has been demonstrated with combined drip irrigation and mulching, in comparison with overhead sprinkler systems [48].

- $\quad$ using antitranspirants (mostly restricted to nurseries, to avoid excessive transpiration in newly transplanted crops). Antitranspirants are wax or plastic compounds that create a film on the leaves, covering the stomata. The effect is the reduction of water losses by transpiration and the reduction of photosynthesis, which means lower water use and improved tolerance of crops to drought stress [49]. Recent studies report that an antitranspirant sprayed on soybeans under a regular or low irrigation rate was able to improve WUE, acting on stomata and leaf gas exchange [50].

- $\quad$ adopting increased distances between rows and along the row in sowing and transplanting, reducing plant density and competition among plants;

- $\quad$ performing pruning or leaf removal in order to reduce the leaf area index;

- $\quad$ implementing a rational use of fertilizers. In this context, organic fertilization is generally useful for positive effects on soil water retention, and phosphate fertilization is often useful because it stimulates radicle growth, while nitrogen fertilization should be limited to avoid increasing concentrations of the circulating solution with greater difficulty in water supply for plants;

- $\quad$ delivering the water supply strictly needed to restore the useful water soil reservoir;

- choosing more efficient irrigation techniques (considering efficiency to be the ratio between water transpired by a crop to water distributed into the field, the mean efficiency is about $80-90 \%$ for drip, subsurface, center pivot or linear irrigation, $60-70 \%$ for sprinkler irrigation, and $30-40 \%$ for surface irrigation).

- $\quad$ selecting species and varieties so that the stage of maximum sensitivity to water stress does not coincide with the period of maximum dryness for the selected environment;

- choosing early sowing that enhances deep soil colonization by roots and in some species/varieties anticipates harvest. In this sense, autumn sowing is preferable for winter crops (wheat, barley, oat, canola, etc.) while early spring sowing is preferable for summer crops. This choice is obviously suitable only for zones that are not prone to frost risk or where early sowing is compatible with the harvest of previous crops;

- $\quad$ using biostimulants that can improve root development or enhance the biosynthesis of osmotic compounds [51]. These metabolites are able to improve crop tolerance and include plant hormones (abscisic acid) proline, sugars, amino acids, etc. The application of biostimulants can be carried out by soil drench or spray.

WUE can be enhanced by a suitable choice of crop species and varieties. An example is soft wheat (Triticum aestivum L.), in which the selection of varieties for the European environment led to varieties suitable for Mediterranean or transitional climates (Csa and Cfa of the Köppen-Geiger climate classification) with the length of the flowering-ripening period reduced with respect to that of varieties suitable for Oceanic environments ( $\mathrm{Cfb}$ of Köppen-Geiger). Other examples are grapevine 
rootstocks from Vitis rupestris Scheele, which are more resistant than those of Vitis Riparia Michx., and sorghum (Sorghum bicolor L.), which in environments prone to drought is preferred to maize (Zea mays L.) because it is able to resume vegetation without excessive production damage after a drought event.

\subsubsection{Precision Farming and Variable-Rate Irrigation}

Soil water content is crucial for managing irrigation and can be measured by means of suitable sensors [52,53] or estimated by water balance models based on the continuity equation (conservation of water applied to the soil reservoir). These technologies allow for selecting irrigation time and volumes.

In recent years, these tools have been used to drive variable-rate irrigation (VRI) [54], which allows for the distribution of different amounts of water in different parts of the same field as a function of soil and crop heterogeneity. This approach can be particularly important for fields characterized by a high variability of soil characteristics (texture, structure, depth, and fertility). In these situations, the combination of precision farming and VRI can reduce water losses and improve the WUE of field crops.

\subsubsection{Grafting as an Agronomic Tool to Improve Drought Tolerance}

WUE can also be improved by means of suitable rootstocks The increase of WUE in plants by grafting can be a reliable agronomic strategy for enhancing crop adaptation and performance in dry environments and, in the past, grafting was widely used in vegetable crops to limit the effects of soil pathogens [55]; more recently, it has been used to induce tolerance against abiotic stresses, such as organic pollutants [56], boron and salinity [57,58], and thermal and water stress. About this latter, it has been shown that the grafting of scions susceptible to water stress onto tolerant rootstocks increased the resistance of grafted trees to this stress [59,60]. Sanders and Markhart [61] have shown that the osmotic potential of dehydrated scions of grafted beans (Phaseolus vulgaris L.) was determined by the rootstocks, while the osmotic potential of non-stressed scions was governed by the shoot [60]. Drought tolerance, provided by either the rootstock or the scion, resulted in enhanced nitrogen fixation in soybeans (Glycine max L.) [61]. Other grafting experiments on the effect of drought on fruit crops, such as kiwis and grapes, proved that drought-tolerant rootstocks are available and useable under commercial conditions [62,63]. In contrast, only a few studies exist with grafted fruit vegetables. Because eggplants are more effective at water uptake than tomato root systems, it could be useful to study the effects of their grafting on WUE under water-stress conditions. Grafting mini-watermelons onto a commercial rootstock (PS 1313: Cucurbita maxima Duchesne $\times$ Cucurbita moschata Duchesne) revealed a $>60 \%$ higher marketable yield when grown under conditions of deficit irrigation compared to non-grafted melons [64].

In response to water stress, the hormone that serves as a link between the rootstock and scion seems to be abscisic acid (ABA), as observed in different species such as Citrus sp. [65] and Vitis sp. [66], but also in cucumber grafts on luffa (Luffa sp. Mill. 1754) [67]. Grafting experiments with ABA-deficient mutants of tomato showed that stomata can close independently of the leaf water status, suggesting that there is a chemical signal produced by the roots that controls stomata conductance [68]. Therefore, the selection of rootstocks with adequate biosynthesis and perception of the ABA could improve the efficient use of water and the drought tolerance of many horticultural varieties. Since Cucurbita is one of the genera most used as rootstocks of different species of Cucurbitaceae (watermelon, melon, cucumber), the identification of mutants with a greater ability to synthesize ABA, or hypersensitivity to ABA, could improve tolerance to plant water stress. This increase in ABA biosynthesis also occurred in ethylene-insensitive mutants [69]. On the other hand, it is known that ABA function in the closure of the stomata is mediated by Reactive Oxygen Species (ROS) production [70]. Therefore, used as rootstocks, ethylene-insensitive and ROS-tolerant mutants could also improve water stress tolerance of vegetables, including post-harvest dehydration of fruit. 


\subsection{Salinity Stress}

Soil salinity is determined by the accumulation of soluble salts, which mainly include $\mathrm{Cl}^{-}, \mathrm{SO}_{4}{ }^{2-}$, $\mathrm{HCO}_{3}{ }^{-}, \mathrm{Na}^{+}, \mathrm{Ca}^{2+}$, and $\mathrm{Mg}^{2+}$. The accumulation of these ions derives from low-quality irrigation water and poor soil drainage [71]. Salinity reduces plant growth and yield when the concentration of salts reaches $4 \mathrm{dS} / \mathrm{m}$. The reduction of growth and yield depends on crops' tolerance (Table 3).

Table 3. Tolerance thresholds expressed as electric conductivity (EC) and critical EC values for yield loss. Tolerance degree expressed as: $\mathrm{S}$ = sensitive; MS = moderately sensitive; $\mathrm{MT}$ = moderately tolerant; $\mathrm{T}=$ tolerant $[72]$.

\begin{tabular}{|c|c|c|c|c|c|c|c|}
\hline \multirow[b]{2}{*}{ Vegetable Crops } & \multicolumn{3}{|c|}{ Soil Salinity } & \multicolumn{3}{|c|}{ Salinity in Irrigation Water } & \multirow[b]{2}{*}{ Tolerance } \\
\hline & $\begin{array}{c}\text { Threshold } \\
(\mathrm{CEe})\left(\mathrm{dS} \cdot \mathrm{m}^{-1}\right)\end{array}$ & $\begin{array}{c}\text { Slope } \\
\left(\% / \mathrm{dS} \cdot \mathrm{m}^{-1}\right)\end{array}$ & $\begin{array}{l}\text { Yield } 0 \% \\
\left(\mathrm{dS} \cdot \mathrm{m}^{-1}\right)\end{array}$ & $\begin{array}{l}\text { Threshold (CEi) } \\
\left(\mathrm{dS} \cdot \mathrm{m}^{-1}\right)\end{array}$ & $\begin{array}{c}\text { Slope } \\
\left(\% / \mathrm{dS} \cdot \mathrm{m}^{-1}\right)\end{array}$ & $\begin{array}{l}\text { Yield } 0 \% \\
\left(\mathrm{dS} \cdot \mathrm{m}^{-1}\right)\end{array}$ & \\
\hline Artichoke (Cynara scolymus L.) & 4.8 & 10.9 & 14 & 2.7 & 14.4 & 9.6 & MT \\
\hline $\begin{array}{c}\text { Asparagus (Asparagus } \\
\text { officinalis L.) }\end{array}$ & 4.1 & 2 & 54.1 & 2.7 & 3.0 & 36 & $\mathrm{~T}$ \\
\hline Bean (Faseolus vulgaris L.) & 1 & 19 & 6.3 & 0.7 & 28.5 & 4.2 & $\mathrm{~S}$ \\
\hline Broad bean (Vicia faba L.) & 1.6 & 9.6 & 12 & 1.1 & 14.5 & 8 & MS \\
\hline $\begin{array}{c}\text { Broccoli (Brassica oleracea var. } \\
\text { italica Plenck) }\end{array}$ & 2.8 & 9.2 & 13.7 & 1.9 & 13.8 & 9.2 & MS \\
\hline $\begin{array}{c}\text { Brussels sprouts (Brassica oleracea } \\
\text { var. gemmifera DC.) }\end{array}$ & - & - & - & - & - & & MS \\
\hline $\begin{array}{c}\text { Cabbage hood (Brassica oleracea } \\
\text { var. capitata L.) }\end{array}$ & 1.8 & 9.7 & 12.1 & 1.2 & 14.6 & 8.1 & MS \\
\hline Carrot (Daucus carota L.) & 1 & 14 & 8.1 & 0.7 & 21.0 & 5.5 & $\mathrm{~S}$ \\
\hline $\begin{array}{c}\text { Cauliflower (Brassica oleracea L. } \\
\text { var. botrytis L.) }\end{array}$ & - & - & - & - & - & - & MS \\
\hline $\begin{array}{l}\text { Celery (Apium graveolens L. var. } \\
\text { dulce [Mill.] Pers.) }\end{array}$ & 1.8 & 6.2 & 17.9 & 1.2 & 9.3 & 12 & MS \\
\hline $\begin{array}{l}\text { Cowpea (Vigna unguiculata [L.] } \\
\text { Walpers subsp. unguiculata) }\end{array}$ & 4.9 & 12 & 13.2 & 3.3 & 18.2 & 8.8 & MT \\
\hline Cucumber (Cucumis sativus L.) & 2.5 & 13 & 10.2 & 1.7 & 19.5 & 6.8 & MS \\
\hline Eggplants (Solanum melongena L.) & 1.1 & 6.9 & 15.6 & 0.7 & 10.3 & 10.4 & MS \\
\hline $\begin{array}{l}\text { Funnel (Foeniculum vulgare Miller } \\
\text { var. azoricum [Mill.] Thell.) }\end{array}$ & 1.5 & 15 & 8.2 & 1.1 & 18.0 & 6.7 & MS \\
\hline Garlic (Allium sativum L.) & 1.7 & 10 & 11.7 & 1.1 & 14.9 & 7.8 & MS \\
\hline Lettuce (Lactuca sativa L.) & 1.3 & 13 & 9 & 0.9 & 19.5 & 6 & MS \\
\hline Melon (Cucumis melo L.) & 1 & 8.4 & 12.9 & 0.7 & 12.7 & 8.6 & MS \\
\hline Onion (Allium cepa L.) & 1.2 & 16 & 7.5 & 0.8 & 24.0 & 5 & S \\
\hline Pea (Pisum sativum L.) & - & - & - & - & - & - & $\mathrm{S}$ \\
\hline Pepper (Capsicum annuum L.) & 1.5 & 14 & 8.6 & 1.0 & 21.0 & 5.8 & MS \\
\hline Potato (Solanum tuberosum L.) & 1.7 & 12 & 10 & 1.1 & 18.0 & 6.7 & MS \\
\hline Radish (Raphanus sativus L.) & 1.2 & 13 & 8.9 & 0.8 & 19.5 & 5.9 & MS \\
\hline Rapa (Brassica rapa L. var. rapa) & 0.9 & 9 & 12 & 0.7 & 13.5 & 8.1 & MS \\
\hline Spinach (Spinacia oleracea L.) & 2 & 7.6 & 15.2 & 1.3 & 11.4 & 10.1 & MS \\
\hline $\begin{array}{l}\text { Straberry (Fragaria } x \\
\text { ananassa Duch.) }\end{array}$ & 1 & 33 & 4.0 & 0.7 & 49.5 & 2.7 & $S$ \\
\hline $\begin{array}{c}\text { Swiss chard (Beta vulgaris L. var. } \\
\text { conditiva Alef.) }\end{array}$ & 4 & 9 & 15.1 & 2.7 & 13.5 & 10.1 & MT \\
\hline $\begin{array}{l}\text { Tomato (Lycopersicon } \\
\text { esculentum Mill.) }\end{array}$ & 2.5 & 9.9 & 12.6 & 1.7 & 15.0 & 8.4 & MS \\
\hline $\begin{array}{c}\text { Water melon (Citrullus lanatus } \\
\text { [Thunberg] Matsumura et Nakai) }\end{array}$ & - & - & - & - & - & - & MS \\
\hline Zucchini (Cucurbita pepo L.) & 4.7 & 9.4 & 15.3 & 3.1 & 14.1 & 10.2 & MT \\
\hline
\end{tabular}

High salinity is often a problem in areas located along the sea, especially in Mediterranean areas with intensive agriculture [73] and, in particular, for vegetable farms. Vegetable crops usually have short production cycles and require substantial amounts of water in short periods, 
increasing salinity problems. The majority of high salinity soil and irrigation water occurs in summer because the reduction of water availability increases seawater infiltration in the groundwater. In these conditions farms that use underground water pumped from soils for irrigation increase seawater infiltration. It has been estimated that half of irrigated agricultural lands are affected by salinity.

Agronomic strategies to reduce salinity stress during cultivation can act on soil or crops. At the soil level, the simplest strategy is to maintain high water availability, with frequent irrigation if possible. It is important to use irrigation systems with high efficiency, such as drip irrigation. The reduction of soil water content increases the salt concentration and crops suffer from osmotic stress. Summer is the most critical period for salinity stress; usually increased plant survival can be obtained by calcium nitrate or chloride [74]. The application of calcium has a beneficial effect on both the soil structure and plant tolerance. The calcium ions move the sodium ions from soil colloids and these can be leached by irrigation. The same effect can be reached by magnesium application. The mitigation effect is considered in the calculation of the sodium adsorption rate (SAR), which takes into consideration the concentration of sodium, calcium, and magnesium, in the following equation:

$$
\mathrm{SAR}=\frac{N a^{+}}{\sqrt{\frac{C a^{2+}+M g^{2+}}{2}}} .
$$

Therefore, fertilizers containing calcium and magnesium in sodic soils improve the structure of soils and provide a better environment for roots and plant growth. At the crop physiology level, cytosolic calcium inhibits sodium channels in membranes, called salt overlay sensitivity (SOS), and reduces salt accumulation in the cells, alleviating salinity stress. The mutation of a gene encoding for a SOS plasma membrane $\mathrm{Na}^{+}-\mathrm{H}^{+}$antiporter increased salt sensitivity, while the overexpression of this gene increased salt tolerance [75]. Moreover, nitrates, if calcium nitrate is used, are in competition with sodium ions for accumulation in the vacuoles. Therefore, the supply of nitrates may reduce salt uptake. However, this particular aspect needs further investigation.

Positive effects have been reported for the application of plant growth-promoting bacteria (PGPB) in increasing crop tolerance to salinity [76]. The mechanism of action has not been elucidated yet but it seems that the bacteria help the roots avoid the excessive uptake of sodium. An analogous effect can be obtained using arbuscular-mycorrhizal fungi, which can improve the uptake of mineral nutrients and reduce salt stress, enhance osmotic adjustment, and have a direct effect on plant hormone biosynthesis. The application of Glomus species in lettuce stressed with sodium chloride improved photosynthetic activity, stomatal conductance, and WUE [77].

\subsection{Lodging}

The process by which shoots of winter or summer cereals are displaced from their vertical orientation is named lodging. In cereals such as wheat and barley, lodging is most likely to occur during the two or three months preceding harvest, usually after ear or panicle emergence, with the result that shoots permanently lean or lie horizontally on the ground. Lodging can be caused by the buckling of stems (stem lodging) or displacement of roots within the soil (root lodging) [78]. In stem lodging, roots are held firm in a strong soil where the wind force buckles one of the lower internodes of the shoot. Root lodging becomes more likely when the anchorage strength is reduced by weak soil or poorly developed anchorage roots. The effect is a reduction in crop yield by up to $80 \%$, with further losses in grain quality, greater drying costs, and an increase in the time taken for harvesting [79].

The main factors that contribute to the lodging process are strong winds (e.g., foehn winds or downbursts associated with thunderstorms), heavy rain, crop pests (e.g., Diabrotica vergifera larvae bore deep into the roots, destroying them and giving rise to root lodging), diseases (e.g., fungal diseases that attack the basal part the stems of winter cereals give rise to stem lodging), and an excess of nitrogen 
fertilization (nitrogen enhances the vegetative growth of stems, with excessive elongation associated with a lower elasticity and increased weakness).

Lodging can be prevented by installing shelterbelts against dominant winds, adopting an equilibrated nitrogen fertilization, choosing a suitable plant density, and optimizing the management of pests and biotic diseases harmful to the stability and mechanic resistance of stems and roots. The lodging risk for crops can also be reduced by the introduction of semi-dwarf varieties (e.g., the wheat varieties produced by Nazareno Strampelli and Norman Borlaug in the 20th century) or by the adoption of plant growth regulators (PGRs).

Wind breaks are barriers given by plantations (trees and shrubs) or non-living material (walls, fences and so all), established in order to protect field crops from dominant winds. A crucial decision in order to optimize the effect of windbreaks is influenced by their porosity, because a very dense or low-density row of trees have low effectiveness, while the most effective are medium-density rows [80]. Numerous studies describe the effect of wind breaks on various atmospheric variables such as temperature (for example, the risk of frost can be increased) and evapotranspiration. Furthermore, shelter belt plantations show a more or less strong competition with crops for light, water, and nutrients [64]. All these effects, which are generally a function of the distance from the windbreak, should be considered in the design of these artifacts.

\section{Conclusions}

This review discussed agronomic strategies that can be adopted to cope with the effects of abiotic stress on crops, offering a series of ideas based on suitable cultivation techniques. Often defense against abiotic stress is only sought at the genetic level by the identification of tolerant genotypes. This is a correct approach, but agronomic tools can often offer an adequate and rapid solution for reducing crop yield losses. The interaction between genetics and management was a crucial factor of the 20th-century green revolution and is destined to receive increasing attention in the coming years due to the need to increase global agricultural production while respecting the quality requirements of the market. Agronomic management strategies have been considered static for a long time and have not been adequately reconsidered for controlling crop performance. Instead, agronomic management has to be continuously revised, considering innovations in crop tolerance and genetic improvements.

Author Contributions: Both authors contributed equally to the review.

Conflicts of Interest: The authors declare no conflict of interest.

\section{References}

1. Zandalinas, S.I.; Mittler, R.; Balfagón, D.; Arbona, V.; Gómez-Cadenas, A. Plant adaptations to the combination of drought and high temperatures. Physiol. Plant. 2017. [CrossRef] [PubMed]

2. Vinocur, B.; Altman, A. Recent advances in engineering plant tolerance to abiotic stress: Achievements and limitations. Curr. Opin. Biotechnol. 2005, 16, 123-132. [CrossRef] [PubMed]

3. Cramer, G.R.; Urano, K.; Delrot, S.; Pezzotti, M.; Shinozaki, K. Effects of abiotic stress on plants: A systems biology perspective. BMC Plant Biol. 2011, 11, 163. [CrossRef] [PubMed]

4. Atkinson, N.J.; Urwin, P.E. The interaction of plant biotic and abiotic stresses: From genes to the field. J. Exp. Bot. 2012, 63, 3523-3543. [CrossRef] [PubMed]

5. Buchanan, B.B.; Gruissem, W.; Russell, L.J. (Eds.) Biochemistry and Molecular Biology of Plants, 2nd ed.; Wiley: Hoboken, NJ, USA, 2015; 1280p, ISBN 978-0-470-71421-8.

6. Boogaard, H.; Wolf, J.; Supit, I.; Niemeyer, S.; van Ittersum, M. A regional implementation of WOFOST for calculating yield gaps of autumn-sown wheat across the European Union. Field Crops Res. 2013, 143, 130-142. [CrossRef]

7. Singh, R.; Van Dam, J.C.; Feddes, R.A. Water productivity analysis of irrigated crops in Sirsa district, India. Agric. Water Manag. 2006, 82, 253-278. [CrossRef]

8. Mariani, L. Carbon plants nutrition and global food security. Eur. Phys. J. Plus 2017, 132, 69. [CrossRef]

9. Oerke, E.C. Crop losses to pests. Centenary review. J. Agric. Sci. 2006, 144, 31-43. [CrossRef] 
10. Boyer, J.S. Plant productivity and environment. Science 1982, 218, 443-448. [CrossRef] [PubMed]

11. Farooq, M.; Wahid, A.; Kobayashi, N.; Fujita, D.; Basra, S.M.A. Plant drought stress: Effects, mechanisms and management. Agron. Sustain. Dev. 2009, 29, 185-212. [CrossRef]

12. Hillel, D. Introduction to Environmental Soil Physics; Elsevier: Amsterdam, The Netherlands, 2013; 495p.

13. Rich, S.M.; Watt, M. Soil conditions and cereal root system architecture: Review and considerations for linking Darwin and Weaver (Darwin review). J. Exp. Bot. 2013, 64, 1193-1208. [CrossRef] [PubMed]

14. Passioura, J.B. Soil conditions and plant growth. Plant Cell Environ. 2002, 25, 311-318. [CrossRef] [PubMed]

15. Pearson, C.J.; Norman, D.W.; Dixon, J. Sustainable Dryland Cropping in Relation to Soil Productivity-FAO Soils Bulletin 72; Food \& Agriculture Organization of the United Nations (FAO): Rome, Italy, 1995.

16. Valentine, T.A.; Hallett, P.D.; Binnie, K.; Young, M.W.; Squire, G.R.; Hawes, C.; Bengough, A.G. Soil strength and macropore volume limit root elongation rates in many UK agricultural soils. Ann. Bot. 2012, 110, 259-270. [CrossRef] [PubMed]

17. Bonciarelli, F. Fondamenti di Agronomia Generale; Edagricole: Bologna, Italy, 1989; 292p.

18. Mariani, L.; Cola, G.; Parisi, S. Dimensioning of field ditches in function of heavy and frequent precipitations. In Proceedings of the AIAM 2013 17th Annual Meeting of the Italian Agrometeorological Association Agrometeorology for Environmental and Food Security, Florence, Italy, 4-6 June 2013. (supplement to the Italian Journal of Agrometeorology 2013, 101-102).

19. Pagliai, M.; Vignozzi, N.; Pellegrini, S. Soil structure and the effect of management practices. Soil Tillage Res. 2004, 79, 131-143. [CrossRef]

20. Kibblewhite, M.G.; Ritz, K.; Swift, M.J. Soil health in agricultural systems. Philos. Trans. R. Soc. Lond. B Biol. Sci. 2008, 363, 685-701. [CrossRef] [PubMed]

21. Carmeis Filho, A.C.A.; Crusciol, C.A.C.; Guimarães, T.M.; Calonego, J.C.; Mooney, S.J. Correction: Impact of amendments on the physical properties of soil under tropical long-term no till conditions. PLoS ONE 2017, 12. [CrossRef] [PubMed]

22. Mulumba, N.L.; Lal, R. Mulching effects on selected soil physical properties. Soil Tillage Res. 2008, 98, 106-111. [CrossRef]

23. Wagner, L.E.; Ambe, N.M.; Barnes, P. Tillage-induced soil aggregate status as influenced by water content. Trans. ASAE 1992, 35, 499-504. [CrossRef]

24. Liu, Z.; Rong, Q.; Zhou, W.; Liang, G. Effects of inorganic and organic amendment on soil chemical properties, enzyme activities, microbial community and soil quality in yellow clayey soil. PLoS ONE 2017, 12, e0172767. [CrossRef] [PubMed]

25. Tejada, M.; Gonzalez, J.L. Influence of organic amendments on soil structure and soil loss under simulated rain. Soil Tillage Res. 2017, 93, 197-205. [CrossRef]

26. Wu, S.F.; Wu, P.T.; Feng, H.; Bu, C.F. Influence of amendments on soil structure and soil loss under simulated rainfall China's loess plateau. Afr. J. Biotechnol. 2010, 9, 6116-6121.

27. Su, L.; Wang, Q.; Wang, C.; Shan, Y. Simulation Models of Leaf Area Index and Yield for Cotton Grown with Different Soil Conditioners. PLoS ONE 2015. [CrossRef] [PubMed]

28. Pearson, C.J.; Norman, D.W.; Dixon, J. Physical aspects of crop productivity. In Sustainable Dryland Cropping in Relation to Soil Productivity, FAO Soils Bulletin 72; Food \& Agriculture Organization of the United Nations (FAO): Rome, Italy, 1995; Chapter 2; Available online: http:/ /www.fao.org/docrep/V9926E/v9926e04.htm (accessed on 22 September 2017).

29. Mohamadi, M.A.; Kavian, A. Effects of rainfall patterns on runoff and soil erosion in field plots. Int. Soil Water Conserv. Res. 2015, 3, 273-281. [CrossRef]

30. NSW DPI Soils Advisory Office. Soil Erosion Solutions, Fact Sheet 1: Types of Erosion. 2017. Available online: https:/ / www.dpi.nsw.gov.au/_data/assets/pdf_file/0003/255153/fact-sheet-1-typesof-erosion.pd (accessed on 3 September 2017).

31. Taguas, E.V.; Guzman, E.; Guzman, G.; Vanwalleghem, T.; Gomez, J.A. Characteristics and Importance of Rill and Gully Erosion. Cuadenos de Investigacion Geografica 2015, 41, 107-126. [CrossRef]

32. Soracco, C.G.; Lozano, L.A.; Villarreal, R.; Palancar, T.C.; Collazo, D.J.; Sarli, G.O.; Filgueira, R.R. Effects of compaction due to machinery traffic on soil pore configuration. Rev. Bras. Ciênc. Solo 2015, 39. [CrossRef]

33. Dagesse, D.F. Freezing cycle effects on water stability of soil aggregates. Can. J. Soil Sci. 2013, 93, 473-483. [CrossRef] 
34. Tennis, E.S.; Dolferus, R.; Ellis, M.; Rahman, M.; Wu, Y.; Hoeren, F.U.; Grover, A.; Ismond, K.P.; Good, A.G.; Peacock, W.J. Molecular strategies for improving waterlogging tolerance in plants. J. Exp. Bot. 2000, 51, 89-97.

35. Drew, M.C. Oxygen deficiency and root metabolism: Injury and acclimation under hypoxia and anoxia. Ann. Rev. Plant Physiol. Plant Mol. Biol. 1997, 48, 223-250. [CrossRef] [PubMed]

36. Linkemer, G.; Board, J.E.; Musgrave, M.E. Waterlogging effects on growth and yield components in late-planted soybean. Crop Sci. 1998, 38, 1576-1584. [CrossRef] [PubMed]

37. Fukao, T.; Bailey-Serres, J. Plant responses to hypoxia-Is survival a balancing act? Trends Plant Sci. 2004, 9, 449-456. [CrossRef] [PubMed]

38. MacEwan, R.J.; Gardner, W.K.; Ellington, A.; Hopkins, D.G.; Bakker, A.C. Tile and mole drainage for control of waterlogging in duplex soils of south-eastern Australia. Aust. J. Exp. Agric. 1992, 32, 865-878. [CrossRef]

39. Huang, B.; Johnson, J.W.; Nesmith, S.; Bridges, D.C. Growth physiological and anatomical responses of two wheat genotypes to waterlogging and nutrient supply. J. Exp. Bot. 1994, 45, 193-202. [CrossRef]

40. Allègre, A.; Silvestre, J.; Morard, P.; Kallerhoff, J.; Pinelli, E. Nitrate reductase regulation in tomato roots by exogenous nitrate: A possible role in tolerance to long-term root anoxia. J. Exp. Bot. 2004, 55, 2625-2634. [CrossRef] [PubMed]

41. Igamberdiev, A.U.; Hill, R.D. Nitrate, $\mathrm{NO}$ and haemoglobin in plant adaptation to hypoxia: An alternative to the classic fermentation pathways. J. Exp. Bot. 2004, 55, 2473-2482. [CrossRef] [PubMed]

42. Serraj, R.; Sinclair, T.R. Osmolyte accumulation: Can it really help increase crop yield under drought conditions? Plant Cell Environ. 2002, 25, 333-341. [CrossRef] [PubMed]

43. Widtsoe, J.A. Dry Farming, a System of Agriculture for Countries under a Low Rainfall; The Mcmillan Company: New York, NY, USA, 1920; p. 501. Available online: http:/ / archive.org/details/dryfarmingasyst01widtgoog (accessed on 15 September 2017).

44. Lipiec, J.; Kuś, J.; Słowińska-Jurkiewicz, A.; Nosalewicz, A. Soil porosity and water infiltration as influenced by tillage methods. Soil Tillage Res. 2006, 89, 210-220. [CrossRef]

45. Bond, J.J.; Willis, W.O. Soil water evaporation: Surface residue rate and placement effects. Soil Sci. Soc. Am. J. 1969, 33, 445-448. [CrossRef]

46. Gupta, S.; Larson, W.E. Estimating soil water retention characteristics from particle size distribution, organic matter percent, and bulk density. Water Resour. Res. 1979, 15, 1633-1635. [CrossRef]

47. Lament, W.J. Plastic mulches for the production of vegetable crops. HortTechnology 1993, 3, 35-39.

48. Kasirajan, S.; Ngouajio, M. Polyethylene and biodegradable mulches for agricultural applications: A review. Agron. Sustain. Dev. 2012, 32, 501-529. [CrossRef]

49. Clough, G.H.; Locascio, S.J.; Olson, S.M. Continuous use of polyethylene mulched beds with overhead or drip irrigation for successive vegetable production. In Proceedings of the 20th National Agriculture Plastics Congress, Portland, OR, USA, 25-27 August 1987; pp. 57-61.

50. Davenport, D.; Hagan, R.; Martin, P. Antitranspirants uses and effects on plant life. Calif. Agric. 1969, 23, 14-16.

51. Shasha, J.I.; Ling, T.O.N.G.; Fusheng, L.I.; Hongna, L.U.; Sien, L.I.; Taisheng, D.U.; Youjie, W.U. Effect of a new antitranspirant on the physiology and water use efficiency of soybean under different irrigation rates in an arid region. Front. Agric. Sci. Eng. 2017, 4, 155-164.

52. Bulgari, R.; Cocetta, G.; Trivellini, A.; Vernieri, P.; Ferrante, A. Application of biostimulants for improving yield and quality of vegetables and floricultural crops. Biol. Agric. Hortic. 2015, 31, 1-17. [CrossRef]

53. Alvino, A.; Marino, S. Remote sensing for irrigation of horticultural crops. Horticulturae 2017, 3, 40. [CrossRef]

54. Dukes, M.D.; Perry, C. Uniformity testing of variable-rate center pivot irrigation control systems. Precis. Agric. 2006, 7, 205. [CrossRef]

55. Schwarz, D.; Rouphael, Y.; Colla, G.; Venema, J.H. Grafting as a tool to improve tolerance of vegetables to abiotic stresses: Thermal stress, water stress and organic pollutants. Sci. Hortic. 2010, 127, 162-171. [CrossRef]

56. Edelstein, M.; Ben-Hur, M.; Plaut, Z. Grafted melons irrigated with fresh or effluent water tolerate excess boron. J. Am. Soc. Hortic. Sci. 2007, 132, 484-491.

57. Edelstein, M.; Plaut, Z.; Ben-Hur, M. Sodium and chloride exclusion and retention by non-grafted and grafted melon and Cucurbita plants. J. Exp. Bot. 2011, 62, 177-184. [CrossRef] [PubMed] 
58. Garcia-Sanchez, F.; Syvertsen, J.P.; Gimeno, V.; Botia, P.; Perez-Perez, J.G. Responses to flooding and drought stress by two citrus rootstock seedlings with different water-use efficiency. Biol. Plant 2007, 130, 532-542. [CrossRef]

59. Satisha, J.; Prakash, G.S.; Bhatt, R.M.; Sampath Kumar, P. Physiological mechanisms of water use efficiency in grape rootstocks under drought conditions. Int. J. Agric. Res. 2007, 2, 159-164.

60. Sanders, P.L.; Markhart, A.H., III. Interspecific grafts demonstrate root system control of leaf water status in water stressed Phaseolus. J. Exp. Bot. 1992, 43, 1563-1567. [CrossRef]

61. Serraj, R.; Sinclair, T.R. Processes contributing to $\mathrm{N}_{2}$-fixation insensitivity to drought in the soybean cultivar Jackson. Crop Sci. 1996, 36, 961-968. [CrossRef]

62. Clearwater, M.J.; Lowe, R.G.; Hofstee, B.J.; Barclay, C.; Mandemaker, A.J.; Blattmann, P. Hydraulic conductance and rootstock effects in grafted vines of kiwifruit. J. Exp. Bot. 2004, 55, 1371-1381. [CrossRef] [PubMed]

63. Rouphael, Y.; Cardarelli, M.; Colla, G.; Rea, E. Yield, mineral composition, water relations, and water use efficiency of grafted mini-watermelon plants under deficit irrigation. HortScience 2008, 43, 730-736.

64. Allario, T.; Brumos, J.; Colmenero-Flores, J.M.; Iglesias, D.J.; Pina, J.A.; Navarro, L.; Talon, M.; Ollitrault, P.; Morillon, R.; Morillon, R. Tetraploid Rangpur lime rootstock increases drought tolerance via enhanced constitutive root abscisic acid production. Plant Cell Environ. 2013, 36, 856-868. [CrossRef] [PubMed]

65. Serra, I.; Strever, A.; Myburgh, P.A.; Deloire, A. The interaction between rootstocks and cultivars (Vitis vinifera L.) to enhance drought tolerance in grapevine. Aust. J. Grape Wine Res. 2014, 20, 1-14. [CrossRef]

66. Liu, S.; Li, H.; Lv, X.; Ahammed, G.J.; Xia, X.; Zhou, J.; Zhou, Y. Grafting cucumber onto luffa improves drought tolerance by increasing ABA biosynthesis and sensitivity. Sci. Rep. 2016, 6, 20212. [CrossRef] [PubMed]

67. Holbrook, N.M.; Shashidhar, V.R.; James, R.A.; Munns, R. Stomatal control in tomato with ABA-deficient roots: Response of grafted plants to soil drying. J. Exp. Bot. 2002, 53, 1503-1514. [PubMed]

68. Corbineau, F.; Xia, Q.; Bailly, C.; El-Maarouf-Bouteau, H. Ethylene, a key factor in the regulation of seed dormancy. Front. Plant Sci. 2014, 5, 539. [CrossRef] [PubMed]

69. Mustilli, A.C.; Merlot, S.; Vavasseur, A.; Fenzi, F.; Giraudat, J. Arabidopsis OST1 protein kinase mediates the regulation of stomatal aperture by abscisic acid and acts upstream of reactive oxygen species production. Plant Cell 2002, 14, 3089-3099. [CrossRef] [PubMed]

70. Bernstein, L. Effects of salinity and sodicity on plant growth. Ann. Rev. Phytopathol. 1975, 13, $295-312$. [CrossRef]

71. Acosta-Motos, J.R.; Ortuño, M.F.; Bernal-Vicente, A.; Diaz-Vivancos, P.; Sanchez-Blanco, M.J.; Hernandez, J.A. Plant Responses to Salt Stress: Adaptive Mechanisms. Agronomy 2017, 7, 18. [CrossRef]

72. FAO. Annex 1. Crop Salt Tolerance Data. Available online: http://www.fao.org/docrep/005/y4263e/ y4263e0e.htm (accessed on 12 September 2017).

73. Jaleel, C.A.; Manivannan, P.; Sankar, B.; Kishorekumar, A.; Gopi, R.; Somasundaram, R.; Panneerselvam, R. Water deficit stress mitigation by calcium chloride in Catharanthus roseus: Effects on oxidative stress. proline metabolism and indole alkaloid accumulation. Colloids Surf. B Biointerfaces 2007, 60, 110-116. [CrossRef] [PubMed]

74. Yang, Q.; Chen, Z.Z.; Zhou, X.F.; Yin, H.B.; Li, X.; Xin, X.F.; Gong, Z. Overexpression of SOS (Salt Overly Sensitive) genes increases salt tolerance in transgenic Arabidopsis. Mol. Plant 2009, 2, 22-31. [CrossRef] [PubMed]

75. Mayak, S.; Tirosh, T.; Glick, B.R. Plant growth-promoting bacteria confer resistance in tomato plants to salt stress. Plant Physiol. Biochem. 2004, 42, 565-572. [CrossRef] [PubMed]

76. Ruiz-Lozano, J.M.; Azcon, R.; Gomez, M. Alleviation of salt stress by arbuscular-mycorrhizal Glomus species in Lactuca sativa plants. Physiol. Plant. 1996, 98, 767-772. [CrossRef]

77. Berry, P.M. Understanding and reducing lodging in cereals. Adv. Agron. 2004, 84, $217-271$.

78. Tams, A.R.; Mooney, S.J.; Berry, P.M. The Effect of Lodging in Cereals on Morphological Properties of the Root-Soil Complex. In Proceedings of the SuperSoil 2004: 3rd Australian New Zealand Soils Conference, Sydney, Australia, 5-9 December 2004. Available online: http://www.regional.org.au/au/ asssi/supersoil2004/s9/oral/1998_tamsa.htm (accessed on 20 September 2017). 
79. Bean, A.; Alperi, R.W.; Federer, C.A. A method for categorizing shelterbelts porosity. Agric. Meteorol. 1975, 14, 417-429. [CrossRef]

80. Campi, P.; Palumbo, A.D.; Mastrorilli, M. Effect of tree windbreaks on microcliamte and wheat productivity in a Mediterrranean environment. Eur. J. Agron. 2009, 30, 220-227. [CrossRef] 